\title{
上腕骨内上顆骨折の骨片が嵌頓した一例
}

\author{
長崎大学 整形外科 \\ 小無田要・秋山寛 治 \\ 衛 藤 正 雄・伊藤 信 之
}

\section{A Case of Displacement of Fractured Medial Epicondyle of the Humerus into the Elbow Joint}

by

\author{
Kaname Komuta, Kanji Akiyama \\ Masao Eto and Nobuyuki Ito \\ Department of Orthopaedic Surgery \\ Nagasaki University School of Medicine
}

\begin{abstract}
Displacement of fractured medial epicondyle of the humerus into the elbow joint is an unusual condition. Recently we have treated one case.

The patient was a 14-year-old man who had injured in volleyball. Initially, there was palsy of the ulnar nerve and range of motion of the elbow was restricted. Five months after the injury, clinical result was favourable and the patient returned to the volleyball club.
\end{abstract}

\section{は じめに}

小児の肘関節部骨折の中で, 上腕骨内上顆骨折は比 較的頻度の高いものであるが, 骨片が肘関節内に嵌頓 する症例は比較的稀である．今回我々は，本症を経験 したので報告する.

症例 : 14歳, 男

主訴：右肘関節部痛と右手尺側の知賞鈍麻

現病歴：昭和63年 5 月 20 日, バレーボールの練習中, 右肩関節約 $50^{\circ}$ 屈曲位, 肘関節伸展位でレシーブした 際，他の選手が右肘に乗りかかり転倒. 右肘関節外反 が強制された．直ちに近医を受診. 右上腕骨内上顆骨 折と診断され，整復操作を受けることなく当院に紹介 された。

現症: 全身所見では著変を認められなかった，右肘 部内側に腫脹があり, 肘関節の自動運動は屈曲 $80^{\circ}$, 伸 展一 $30^{\circ}$ の範囲で可能であった。最大伸展位で約 $30^{\circ}$ 外 反を呈していた。また右手尺骨神経支配領域の知党低 下が見られた。

$\mathrm{X}$ 線所見: 肘関節前後像では, 内側関節裂隙の拡大 と内上顆の欠損および腕尺関節内に骨片が認められた (図 $1 \mathrm{a}$ ). 側面像では, この骨片は関節内に嵌頓して
いる所見が認められた（困 2 b).

直ちに，伝達麻酔下に手術を行った。

手術所見：右肘関節内後方に縦皮切を加えて侵入し た。内上顆骨片は前腕屈筋群および内側側副靶帯の anterior band が付着したまま肘関節内に嵌頓してい た. 尺骨神経は前腕屈筋群に裁引され浮腫状であった。 嵌頓した内上顆骨片を原位置に整復しKirschner 鋼線 2 本で固定した. 術後, 时関節 $90^{\circ}$ 屈曲位, 手関節軽度 掌屈位にてギプス固定を行った.

術後経過: 術後 4 週間のギプス固定後, 自動運動を 開始し, 11週後抜釘した。

5 ヶ月後のX線像では良好な骨癒合が得られ, 内外 反ストレス撮影でも，側方動摇性は認められなかった

(図 2 ). 肘関節可動域は屈曲 $140^{\circ}$, 伸展 $-5^{\circ}$; 前腕 の回外 $90^{\circ}$, 回内 $80^{\circ}$ とほほ健側と同程度になった。

尺骨神経支配領域の知覚鈍麻は, 術後 4 週で改善し, 尺骨神経伝導速度 (MCV) も $52 \mathrm{~m} / \mathrm{sec}$ と健側と変わら なかった.

しかし, 5 力月後現在, 握力は患側 $30 \mathrm{~kg}$ 健側 $37 \mathrm{~kg}$ と低下している.

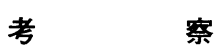






a

b

図 1 術前
a. 正面像で内側関節裂隙の拡大と 腕尺関節内に骨片を認める。
b. 側面像でも関節内に骨片が嵌頓 している所見が認められる。

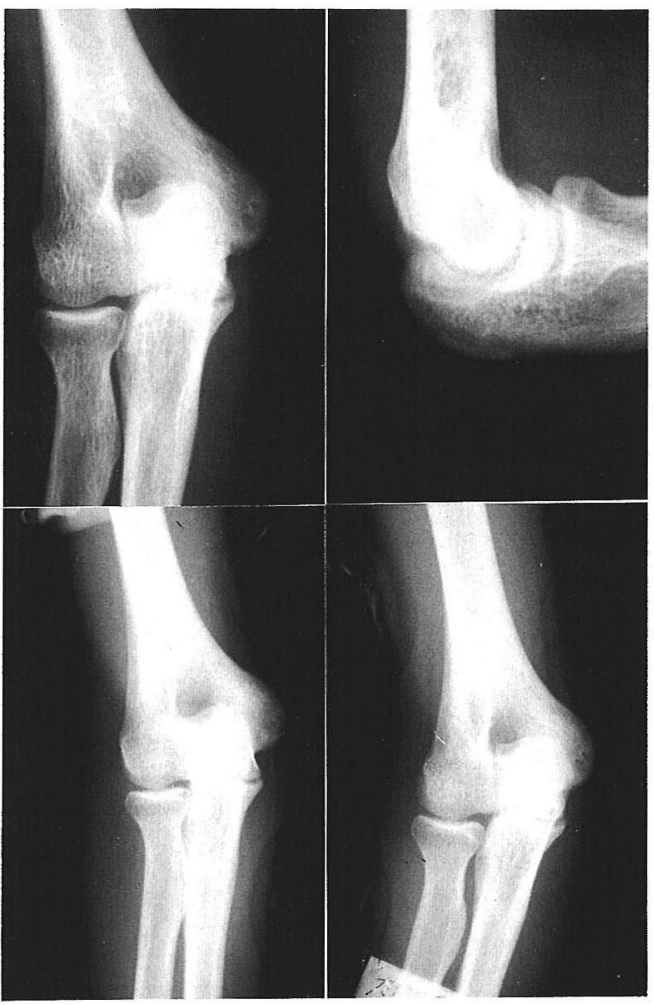

図 2 術後 5 力月

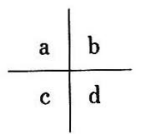

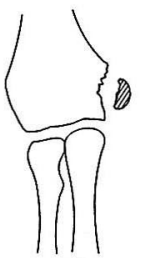


1 型

3 型

4 型

図 3 上腕骨内上顆骨折の Watson- Jones による分類

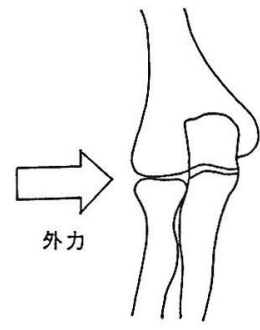

1

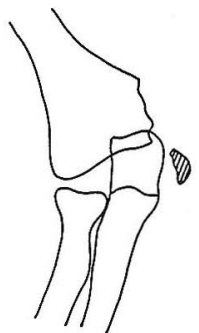

2

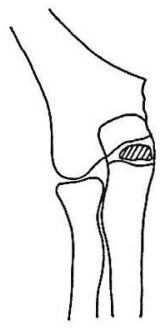

3
图 4 Patrick の一次的骨片嵌入説 Patrickの論文を参考にして図示した。
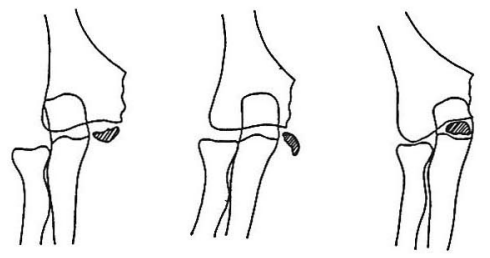

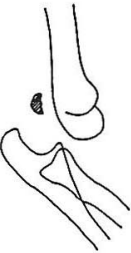

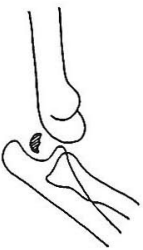

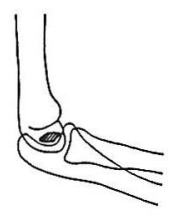

3
图 5 Fêbreの二次的骨片嵌入説

Fêbreの論文を参考にして困示した。

上腕骨内上顆骨折は，小児肘関節部骨折のうち約 10 \%を占めると言われている。

Watson Jone ${ }^{22)}$ は上腕骨内上顆骨折を 4 型に分類 した (図 3 ). その 3 型が剝離した骨片の肘関節内嵌頓 型で，その発生頻度は土肥ら"によれば25例中 1 例で ある。本邦では1950年神中により 4 例が報告されて以 
来，我々が調査した限りでは 44 例 ${ }^{1,3)-17), 19)-21,231,24) . の ~}$ 報告をみる．しかし欧米での報告例は比較的多く，実 際には本邦でもかなりの例が報告されずにあるとも考 えられる。

発生機序について; Patrick ${ }^{18)}$ は, 強力な外転力に より剝離し，関節の高さまで引き下げられた内上顆骨 片が，関節内に形成された一時的な陰圧により吸引さ れるという一次的骨片嵌入説を唱えた (図4). 一方, $F^{2} b^{2} e^{2)}$ らは，肘関節後方脱臼に合併した内上顆骨片 が，脱臼整復時に二次的に嵌入するという二次的骨片 嵌入説を唱えた (図 5 )。 また富永 ${ }^{21)}$ は, 受傷時, 肘関 節構造に不安定性あるいは不適合性が生じ，自然ある いは徒手整復による適合性復帰の瞬間に骨片が嵌入す る.したがって一次性にしろ二次性にしろ本質的に相 違はないと述べている，我々の症例では，受傷時の様 子から考えると脱臼所見はなく，また整復操作も受け ていないためFébre らの脱臼整復に伴う二次的骨片 嵌入説は考えられず, Patrickの一次的骨片嵌入説に 該当するものと思われる.

予後について；本邦で報告された44例中，15例が尺 骨神経麻痺を呈したと報告された。このうち12例が知 覚障害のみであり術後 9 例が治瘉， 2 例がほぼ治癒と いう結果が得られた。運動障害も伴っていた 3 例は追 跡期間が短いため明らかな結果は得られなかった.

術後の関節可動域が21例報告され，このうち15例で 良好な結果が得られ，残りの 6 例は陳旧例および追跡 期間の短いものであった。

前述の如く，尺骨神経麻瘏，関節可動域は術後ほほ 良好な結果が得られている. 我々の症例でも術後 5 力 月現在, 神経障害なく, 関節可動域も健側とほぼ同程 度になっている.

結語

我々は，14歳男で，比較的稀とされている上腕骨内 上顆骨折の骨片が，时関節内に嵌頓した一例を経験し たので報告した。

\section{文献}

1）土肥恒夫ほか：尺骨神経麻㾝を合併した上腕骨内上 顆骨折片関節内嵌入の 1 例, 整形外科, $33: 923-926$, 1982.

2) Fêbre, M. et al.: La reduction non sanglante des fractures de l'epitrochlee avec interposition de ce fragment dans l'interlingne articulaire du Coude. Rev. d'Orthop., $20: 300-314,1933$.

3）神中正一ほか：上腕骨尺側上顆骨片の関節内嵌入の 発生とその治療法について. 整形外科, $1: 257-261$, 1950.

4）彦坂一雄ほか：上腕骨内側上顆骨折片関節内嵌入の 3 例, 中部整災誌, $28: 1889-1890,1985$.

5）平井三千夫ほか：上腕骨内上顆骨折の治療経験。整 形・災害外科, $30: 207-210,1987$.

6）井上博：肘関節部骨折. 季刊関節外科, 4:295$303,1985$.

7）石崎仁英ほか：上腕骨内上顆骨折片関節内嵌入の 1 例. 北海道整災誌，20：272，1975.

8）亀掛川滋：上腕骨尺側上顆骨折片の関節内嵌入例. 臨外, $11: 345,1956$.

9）菊池達也ほか：上腕骨内側上顆の嵌入脱臼骨折の 3 症例. 東北整災外紀要, $11: 131-138,1967$.

10）小比賀薰ほか：肘関節脱臼および脱臼骨折の治療. 季刊関節外科, $3: 307-310,1984$.

11）小島博司ほか：上腕骨内側上顆骨折片の肘関節内嵌 入の一例. 中部日整災外会誌，26：1949，1983.

12）丸山正広ほか：上腕骨内側上顆骨折 肘関節の脱臼 を伴い骨片が関節内に嵌入した 1 例. 信州医誌，35： 672-673, 1987.

13）宮崎正晴ほか：上腕骨尺側上顆骨片の関節内嵌入の 一例. 整外と災外, $6: 208,1956$.

14）村山司：肘関節内に骨片の嵌入せる尺側上顆骨折の 一例. 久留米医誌, $22: 863,1958$.

15）中村登喜雄ほか：上腕骨尺側上顆骨折片の肘関節内 嵌入について. 災害医学, $4: 433,1962$.

16）大場俊二ほか：上腕骨内上顆骨折骨片の関節内嵌入 の 4 例. 整形·災害外科, $26: 681-685,1983$.

17）大島正義ほか：小児内上顆骨折の治療経験。中部整 災誌，24：494，1980.

18) Patrick: Fracture of the medial epicondyle with displacement into the elbow joint, J. Bone Joint Surg. $28: 143,1946$.

19）桜井修ほか：上腕骨内上顆骨折片関節内嵌入の一例. 整形外科, $16: 528,1965$.

20）武田信巳ほか：スポーツに起因する比較的稀な骨折 の 2 症例. 静岡総合病医誌, $2: 75-80,1986$.

21）富永通裕：上腕骨尺側上顆骨折の肘関節内嵌入の発 生機転ならびに治療法に関して. 臨外, $15 ： 829-833$, 1960.

22) Watson-Jones: Fractures and Joint Injuries. 5th ed., Livingstone, Edinburgh, 2 :644-646, 1976.

23）矢野楨二ほか：小児の肘関節部の骨折および脱臼. 災害医学, $16: 709-717,1973$.

24）吉野瞭ほか：上腕骨尺側上顆骨折片の関節内嵌入の 一例. 日整会誌, $36: 158,1962$. 


\section{質 問}

Watson-Jones III型が果して存在するのか疑問です. とくに陰圧が嵌入の原因とは考えられません，脱臼自 然整復中に嵌入したと考えるのが妥当と思いますが.

\section{解 答}

長崎大学 小無田 要 かったものと判断されました。しかし肘関節脱臼は容 易に整復されることもあるため，そういう点からする と脱臼はなかったとは言いきれません. 